\title{
Effect of system rice intensification on microbial population, nutrient status, growth and yield of rice
}

\author{
K. RAJENDRAN* AND V. GANESA RAJA ${ }^{1}$ \\ Central Institute for Cotton Research (I.C.A.R.), COIMBATORE (T.N.) INDIA (Email : kr_agro@
}

\begin{abstract}
Field experiments were carried out during Rabi 2007-08 and 2008-09, to evaluate the crop establishment techniques and weed management practices under system of rice intensification. The experiments were laid out in Split Plot Design with three replications with main plot consisted of three levels age of seedlings viz., 14, 18 and 22 days old seedlings were evaluated with two levels of planting methods viz., SRI planting and mechanical planting. Four levels of weed management practices viz., hand weeding two times at 25 and 45 DAT,

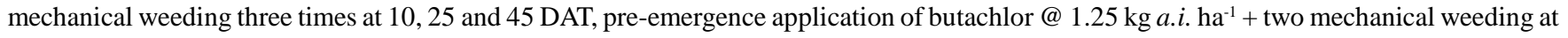
25 and 45 DAT and unweeded check were assigned to sub plot. Transplanting of 14 days old seedlings with manual planting and pre-emergence application of butachlor @ $1.25 \mathrm{~kg}$ a.i. ha ${ }^{-1}+$ two mechanical weeding at 25 and 45 DAT significantly higher microbial population, nutrient uptake and improved the growth parameters, yield attributes and yield of rice.
\end{abstract}

Key Words : SRI, Age of seedlings, Planting methods, Nutrient uptake, Yield

View Point Article : Rajendran, K. and Raja, V. Ganesa (2015). Effect of system rice intensification on microbial population, nutrient status, growth and yield of rice. Internat. J. agric. Sci., 11 (1): 24-29.

Article History : Received : 08.03.2014; Revised : 24.10.2014; Accepted : 10.11.2014

\footnotetext{
* Author for correspondence

${ }^{1}$ Department of Agronomy, Agricultural College and Research Institute (T.N.A.U.), MADURAI (T.N.) INDIA
} 